\title{
Novel use of XRF in the adsorption processes for the direct analysis of cadmium and silver in absorbent $\mathrm{Na}$-alginate beads
}

\author{
Nadia Mahmoud Tawfiq Jebril
}

School of Biological Sciences, College of Sciences for Women, University of Babylon, Iraq

E-mail: dr.nadiajebril@gmail.com

ORCID ID: https://orcid.org/0000-0002-5368-2127

\author{
Received 17/1/2019, Accepted 4/9/2019, Published 1/12/2020
}

This work is licensed under a Creative Commons Attribution 4.0 International License.

\begin{abstract}
:
The Na-alginate bead is commonly used in biotechnology fields such as adsorption due to ion exchange between $\mathrm{Ca}$ and $\mathrm{Na}$ with elements. Scanning electron microscopy (SEM-EDX) has proven to be a comparative method in the detections of these adsorbed elements, but the un-flat forming area of beads that can introduce impossible of the detection of element adsorbed. In contrast, X-ray fluorescence (XRF) documents analysis of elements, direct examination, which may analysis the adsorbents of elements. Here, this Study evaluated the possibility by using XRF for the direct analysis for examples of $\mathrm{Cd}$ and $\mathrm{Ag}$ in a bench stand. This Study compared this to commonly used SEM-EDX and inductively coupled plasma mass spectrometry (ICP-MS) approaches for Cd and Ag analyses. Overall, novel use of XRF provided precise analyses of the concentrations of $\mathrm{Cd}$ and $\mathrm{Ag}$ adsorbed within Na-alginate bead and revealed analyses not determined the concentrations in standard SEM-EDX or previously established in other studies of Naalginate beads. In addition, this Study shows that XRF may be employed in different fields in biotechnology to analysis the concentrations regarding the elemental adsorption of Na-alginate beads and demonstrate the potential for XRF to monitor the procedures underpinning biotechnology sectors.
\end{abstract}

Key words: adsorption, biotechnology sectors, Na-alginate bead, XRF, SEM-EDX, ICP-MS.

\section{Introduction:}

Na-alginate beads are used widely in immobilization biotechnology (1) for producing the drug in an immobilized plant (2) and hydrogen production (3), in addition to the comprehensive using in bioremediation of contaminants (4). The determination of elements in the Na-alginate beads to evaluate either the ability to use immobilized Naalginate beads or the differences between the beads and untreated beads in the specific application such as absorption of contaminants have been repeatedly carried out by element-peak detection using SEMEDX $(5,6)$. SEM-EDX can give the approximate compositions of the elements that appear in different peaks, reflecting the ratio of the elements within the selected section under SEM-EDX analysis. For example, peaks of $\mathrm{Ca}$ in Na-alginate beads produce a higher peak due to the subcomposition. However, the low concentrations of elements within Na-alginate beads and the complexity of these beads makes challenging the peak detection. Also, it is difficult for taking EDX analysis for the section within a bead as $\mathrm{Na}$-alginate bead forms pour that makes un-flat section. The un- flat section is not suitable for EDX analysis as EDX beam detects elements in flat and nearest section to it. However, the further process could be possible for analyses of an element with un-flat section, polish. Currently, un-flat samples are polished using a semi-automatic polishing machine with diamond abrasives to produce a flat section with a $0.25 \mu \mathrm{m}$ that washed with ethanol for $5 \mathrm{~min}$ up to three times and dried for an hour at $80{ }^{\circ} \mathrm{C}$ in an oven (7). This polished process sometimes causes surface damage to samples, therefore study the suitable and concentration of a material polishing powder is important (8) that consumes time and cost. XRF has not been used in the direct analysis of trace elements generally within Na-alginate beads, as no contribution dealing with element determinations by XRF method after using Na-alginate beads in biotechnology sectors or absorption specifically $(9$, $10,11,12,13,14)$.

In the present work, Na-alginate beads have been used for adsorption of $\mathrm{Cd}$ and $\mathrm{Ag}$ from artificial wastewater (AWW) for further determinations of absorbed $\mathrm{Cd}$ and $\mathrm{Ag}$ within the 
beads by XRF approach. This hypothesis of using $\mathrm{XRF}$ for determining $\mathrm{Cd}$ and $\mathrm{Ag}$ within $\mathrm{Na}$-alginate beads based on the hypothesis of Bull et al. (15) in the using XRF for also, direct analysis of trace elements in the marine algae rather than using ICPMS or ICP-OES analyses. The preparation and characterization of $\mathrm{Na}$-alginate beads were also presented here. Adsorption assays for $\mathrm{Cd}$ and $\mathrm{Ag}$ using Na-alginate beads were carried out in the batch adsorption experiments. For the comparative analysis firstly, possible independent analyses of fixative Na-alginate beads were carried out by SEM-EDX. Secondly, ICP-MS analysis was performed on beads. XRF analysis was carried out in a bench stand, and the potential using of XRF for analyzing elements within Na-alginate beads was discussed in terms of using XRF of direct monitoring of the elements within Na-alginate beads in biotechnology sectors.

\section{Methodology:}

\section{Preparation of AWW}

AWW was prepared in sterilized $\mathrm{ddH}_{2} \mathrm{O}$ according to (16) and used within 24 hours.

\section{Na-alginate beads preparation and adsorption} experiments of $\mathbf{C d}$ and $\mathrm{Ag}$

$3 \%(w / v)$ of sodium alginate powder was dissolved in sterilized $\mathrm{ddH}_{2} \mathrm{O}$ and stirred for an hour at $60{ }^{\circ} \mathrm{C}$. The sodium alginate was loaded into a syringe size $1 \mathrm{~mL}$ without its needle and dropped into $100 \mathrm{~mL}$ of $\mathrm{CaCl}_{2}(2 \% \mathrm{w} / \mathrm{v})$. The formed beads were left for an hour to harden, and then removed by a sieve, washed out with $500 \mathrm{~mL}$ of sterilized $\mathrm{ddH}_{2} \mathrm{O}$, kept at $4{ }^{\circ} \mathrm{C}$ and used within 48 hours (17).

\section{Characterizations of Na-alginate beads}

The diameters of the beads were measured by a micrometer, and the masses of beads were measured using a sensitive balance (model Pioneer, Ohaus Company).

\section{$\mathrm{Cd}$ and $\mathrm{Ag}$ adsorption experiments}

Adsorption experiments were carried out in a batch flask in order to get $\mathrm{Cd}$ and $\mathrm{Ag}$ adsorbed into Na-alginate beads prior investigation of the novel use of direct analysis by XRF for $\mathrm{Cd}$ and $\mathrm{Ag}$. Experiments were performed separately for adsorption $\mathrm{Cd}$ and $\mathrm{Ag}$ in $250 \mathrm{~mL}$ Erlenmeyer flasks in triplicates containing $50 \mathrm{~mL}$ wastewater supplemented with initial concentrations 100, 200, 300,400 and $\mu \mathrm{g} / \mathrm{L}$ of either $\mathrm{Cd}$ or $\mathrm{Ag}$ and incubated at $37^{\circ} \mathrm{C}$ for two days in a rotary shaker at $100 \mathrm{rpm}$. These beads, referred to as 'absorbent', were considered to contain a range of elevated concentrations of $\mathrm{Cd}$ and $\mathrm{Ag}$ as well as of some elements from the composition of AWW such as N, $\mathrm{H}, \mathrm{Cl}, \mathrm{K}, \mathrm{H}, \mathrm{P}, \mathrm{O}, \mathrm{Na}$ and $\mathrm{C}$. After adsorption days, the supernatants of AWW were separated and analyzed by ICP-MS. Absorbent Na-alginate beads were washed with $\mathrm{NaCl}(0.9 \mathrm{w} / \mathrm{v})$ and stored at -20 ${ }^{\circ} \mathrm{C}$ prior using for either XRF analysis or fixation for SEM analysis. In terms of checking the ability of Na- alginate beads in adsorption of $\mathrm{Cd}$ and $\mathrm{Ag}$ from AWW along with its control beads, adsorption $(Q)$ of determining $\mathrm{Cd}$ and $\mathrm{Ag}$ in the AWW was calculated according to de Carvalho et al. (18) as equation below:

$$
Q(\%)=\left(C_{0}-C_{\mathrm{i}} / C_{0}\right) / 100
$$

Where $C_{0}$ is the initial concentrations of $\mathrm{Cd}$ and $\mathrm{Ag}$ in the wastewater and $C_{\mathrm{i}}$ is the concentration of $\mathrm{Cd}$ and $\mathrm{Ag}$ after two days of the adsorption experiments.

\section{XRF analysis}

$\mathrm{Cd}$ and Ag loaded Na-alginate beads which have been used in adsorption assay were analyzed by XRF using a Niton XRF analyzer (model XL3T). In terms of comparing drying and freezing methods on XRF analyses in smoothness and thickness, the loaded Na-alginate beads were divided into two parts, one part of the bead was dried at $80^{\circ} \mathrm{C}$ in an oven for 24 hours, and the other part was frozen and froze -also dried, for 24 hours according to Bull et al. (15). For each part, the beads were filed into an XRF cup (downside was polypropylene thin film $4 \mu \mathrm{M}$ ) into the thickness < $10 \mathrm{~mm}$ according to Turner and Solman (19) using 10c coin fixed marker-pen, covered by polypropylene thin film $(4 \mu \mathrm{M})$ and placed above the window of XRF. The concentrations of $\mathrm{Cd}$ and $\mathrm{Ag}$ were measured for a period counting 180 seconds at $20 \mathrm{KV}$. Two Certificated Reference Materials (CRM) of $\mathrm{Cd}$ and $\mathrm{Ag}$ in soil, low and high values (clay loam MLS) were used to verify precision and accuracy as no market CRM for the bead is available, and the accuracies were $89 \%$ and $92 \%$, respectively.

\section{Fixation of $\mathrm{Cd}$ and $\mathrm{Ag}$ loaded Na-alginate beads and analysis by SEM-EDX}

For comparative analysis in the undirected analysis of adsorbed $\mathrm{Cd}$ and $\mathrm{Ag}$ by $\mathrm{Na}$-alginate beads, the $\mathrm{Cd}$ and $\mathrm{Ag}$ loaded Na-alginate beads were fixed using the EDC technique (n-(3dimethylaminopropyl) - $n$ '- ethyl- carbodiimide) according to our protocol (20) prior for SEM-EDX analysis. The beads were cut, fixed and hydrated in serials ethanol concentrations. Then the fixative beads were dried by a critical point drier (EMTECH K850) and coated with gold prior SEM-EDX analysis using SEM analyzer (JEOL-JSM-6610LV).

\section{ICP-MS analyses of $\mathrm{Cd}$ and $\mathrm{Ag}$}

The initial and final concentrations of $\mathrm{Cd}$ and $\mathrm{Ag}$ in $\mathrm{AWW}$ in the adsorption experiments were determined by ICP-MS analysis. Also, $\mathrm{Cd}$ and $\mathrm{Ag}$ loaded Na-alginate beads were analyzed (the 
weight-adjusted to be the same in the XRF cup) after aqua regia digestion The water samples were acidification directly after collecting by adding $1 \%$ $(v / v) \mathrm{HNO}_{3}$ and $50 \mu \mathrm{g} / \mathrm{L}$ of indium for correction of $\mathrm{Cd}$ and $\mathrm{Ag}$ losing, in addition of using yttrium (50 $\mu \mathrm{g} / \mathrm{L})$ as an internal standard for the correction of the instrument. ICP-MS was authenticated by evaluating the limit of detection (LOD), the limit of quantities (LOQ), precision, and accuracy. The LOD of $\mathrm{Cd}$ and $\mathrm{Ag}$ were $0.02 \pm 0.001 \mu \mathrm{M}$, and $0.03 \pm 0.001 \mu \mathrm{M}$, respectively. While the LOQs of $\mathrm{Cd}$ and $\mathrm{Ag}$ were $0.023 \pm 0.002 \mu \mathrm{M}$ and $0.03 \pm 0.001$ $\mu \mathrm{M}$, respectively. The precision (RSD) was $\mathrm{Cd}$ $(0.21 \%)$ and $\mathrm{Ag}(0.43 \%)$. A spike recovery test was performed to check the accuracy and were $96 \pm 0.02$ $\%(\mathrm{Cd})$ and $94 \pm 0.01 \%(\mathrm{Ag})$.

\section{Results and Discussion:}

\section{Characterizations of $\mathrm{Na}$-alginate beads}

The bead diameter of beads was almost equal; giving mean bead diameters in the range of $3.0-$ $3.12 \mathrm{~mm}$ (Figure 1).

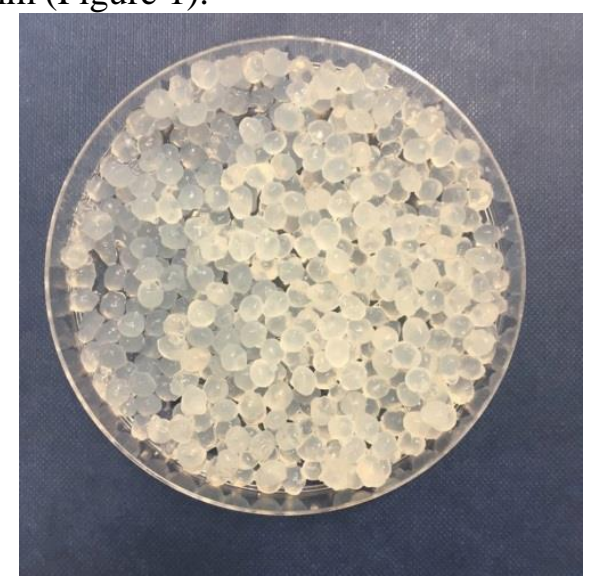

Figure 1. Na-alginate beads.

\section{$\mathrm{Cd}$ and $\mathrm{Ag}$ adsorption experiments}

The analysis of adsorption experiments is not only useful for explaining mechanisms and amounts of adsorptions but also for evaluating the optimum method, including analytical chemistry for analysis absorbed $\mathrm{Cd}$ and $\mathrm{Ag}$ within Na-alginate beads. The batch adsorption experiments showed a higher percentage of adsorption were for $\mathrm{Ag}$ adsorption (Error! Reference source not found.). Also, the percentages of adsorption were decreased with the increases in the initial concentrations of $\mathrm{Cd}$ and Ag. This decline in adsorption probably due to ion exchange between $\mathrm{Ca}$ and $\mathrm{Na}$ or adsorption in the Na-alginate beads with the $\mathrm{Cd}$ and $\mathrm{Ag}$ in the AWW (21). Na-alginate beads were able to adsorb some of either $\mathrm{Cd}$ and $\mathrm{Ag}$ in batch experiments as literary has been founded Nasrullah et al. (22) even in low percentages in the aim of just obtaining $\mathrm{Cd}$ and Ag-loaded within Na-alginate beads.

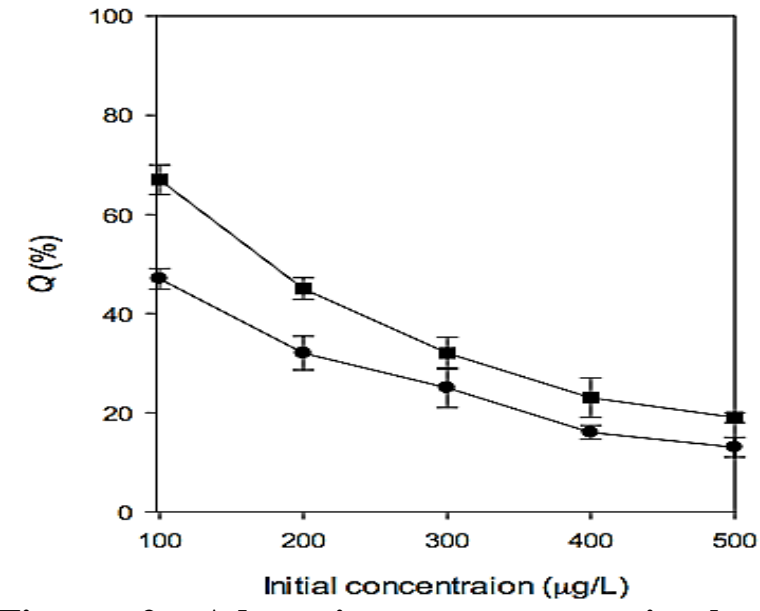

Figure 2. Adsorption percentages in batch experiments. (ש) Ag and (•) Cd in $50 \mathrm{~mL}$ of AWW supplemented with initial nominated concentrations: 100, 200, 300, 400 and $500 \mu \mathrm{g} / \mathrm{L}$ and incubated at $37{ }^{\circ} \mathrm{C}$ for two days in a rotary shaker at $100 \mathrm{rpm}$.

\section{XRF Analysis}

The XRF analysis was carried out of the $\mathrm{Cd}$ and Ag-loaded Na-alginate beads after adsorptions in the higher concentration of $\mathrm{Cd}$ and $\mathrm{Ag}$ (500 $\mu \mathrm{g} / \mathrm{L})$. The results showed that $\mathrm{Ag}$ recorded higher concentration in the Ag-loaded Na-alginate beads $(88.11 \pm 2.00 \mu \mathrm{g} \mathrm{Ag} / \mathrm{g}$ dry weight $)$ than $\mathrm{Cd}$ concentration in the Cd-loaded $\mathrm{Na}$ - alginate bead (64.6 $\pm 1.3 \mu \mathrm{g} \mathrm{Cd} / \mathrm{g}$ dry weight) (Error! Reference source not found.). In terms of differences between the use of two dry methods of pre-measured beads by XRF analysis, the highest concentrations of either $\mathrm{Cd}$ or $\mathrm{Ag}$ were recorded in the beads, which dried at $80{ }^{\circ} \mathrm{C}$ from the beads that were first frozen and then dried, different from the results of Bull et al. (15) as no any differences they recorded. Perhaps due to the differences in the concentrations of $\mathrm{Cd}$ and $\mathrm{Ag}$ adsorbed into the beads, as the adsorption amounts were varied.

Table 1. The mean concentrations of cadmium and silver within loaded Na-alginate beads detected by XRF. The dried beads at $-80{ }^{\circ} \mathrm{C}$ in an oven for 24 hours and the frozen and freezedried of $\mathrm{Cd}$ and Ag-loaded Na-alginate beads after adsorptions. \pm presents the standard error of the mean.

\begin{tabular}{ccc}
\hline $\begin{array}{c}\text { Dried at } 80^{\circ} \mathrm{C} \\
\text { in an oven for } \\
24 \mathrm{~h}\end{array}$ & $\begin{array}{c}64.6 \pm 1.3 \mu \mathrm{gCd} / \\
\mathrm{g} \text { dry weight }\end{array}$ & $\begin{array}{c}88.1 \pm 2.00 \mu \mathrm{gAg} / \\
\mathrm{g} \text { dry weight }\end{array}$ \\
\hline $\begin{array}{c}\text { Frozen and } \\
\text { freeze-dried }\end{array}$ & $\begin{array}{c}43.2 \pm 0.9 \mu \mathrm{gCd} / \\
\mathrm{g} \text { dry weight }\end{array}$ & $\begin{array}{c}76.6 \pm 1.2 \mu \mathrm{g} \mathrm{Ag} / \\
\mathrm{g} \text { dry weight }\end{array}$ \\
\hline
\end{tabular}


A comparison of $\mathrm{Cd}$ and $\mathrm{Ag}$ concentrations measured by XRF, ICP-MS and SEM-EDX analysis

Undirected measurement of $\mathrm{Cd}$ and $\mathrm{Ag}$ concentrations in the $\mathrm{Cd}$ and $\mathrm{Ag}$-loaded $\mathrm{Na}$-alginate bead was subsequently fixed by EDC method, observed and analyzed under SEM-EDX. The results showed the $\mathrm{Cd}$ presents low peak in contrast to the peak of $\mathrm{Ag}$ (Error! Reference source not found.B and Error! Reference source not found. $B)$.

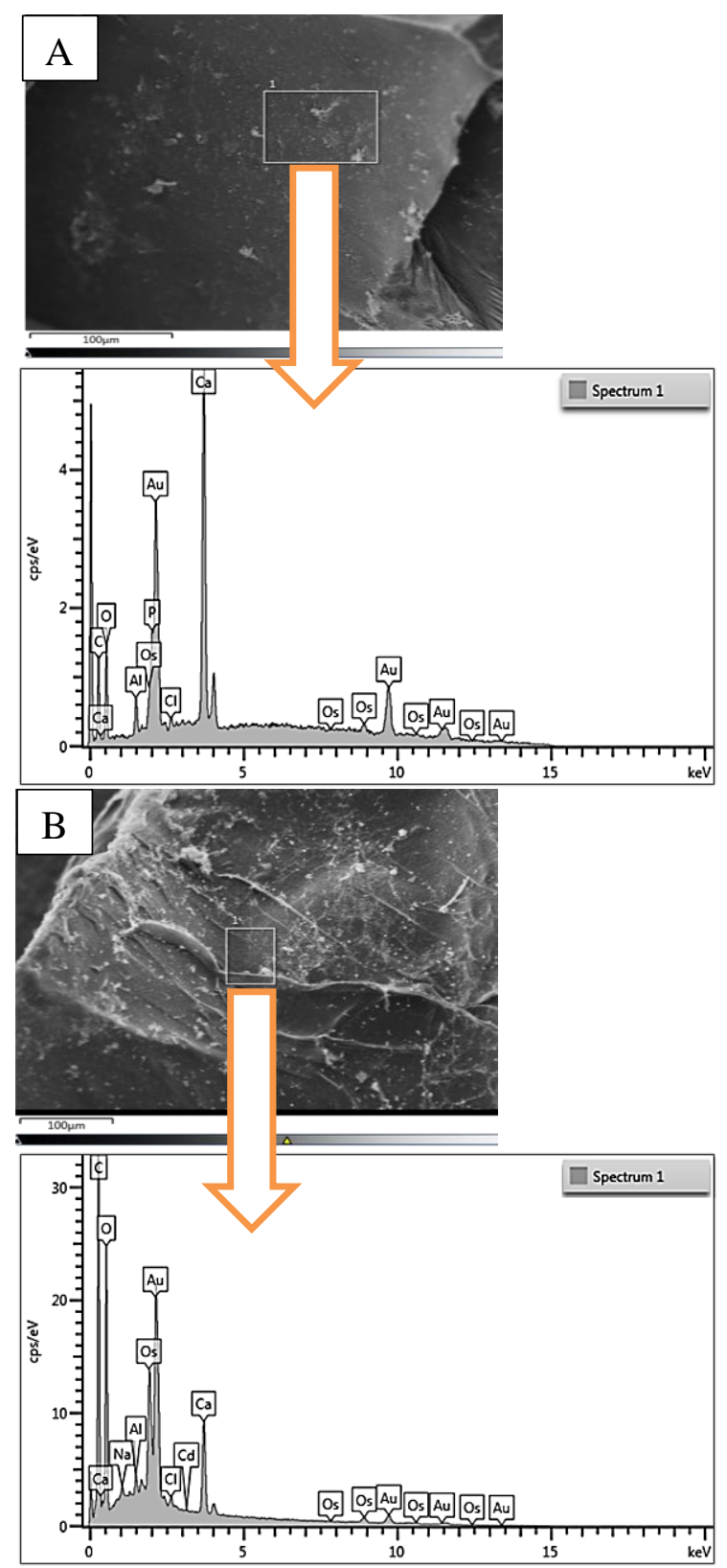

Figure 3. SEM and SEM-EDX observations at a voltage of $12 \mathrm{~V}$. (A) Na-alginate bead before the adsorption. (B) Cd-loaded Na-alginate beads after Cd adsorption of initial concentration (500 $\mu \mathrm{g} / \mathrm{L}$ ) in the $\mathrm{AWW}$ incubated at $37{ }^{\circ} \mathrm{C}$ for two days in a rotary shaker at $100 \mathrm{rpm}$.
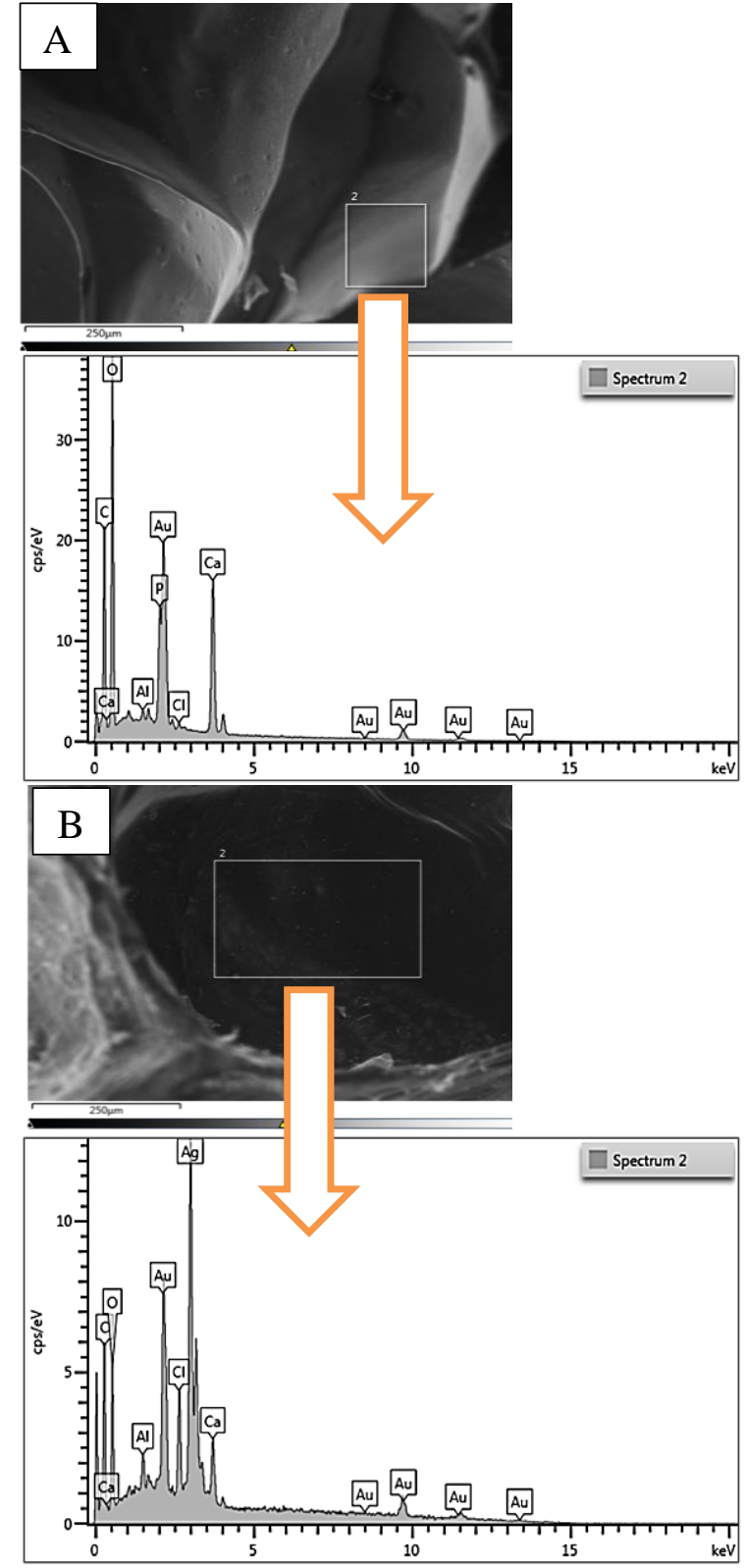

Figure 4. SEM and SEM-EDX observations at a voltage of $12 \mathrm{~V}$. (A) Na-alginate bead before the adsorption. (B) Ag-loaded Na-alginate beads after Ag adsorption of initial concentration (500 $\mu \mathrm{g} / \mathrm{L}$ ) in the $\mathrm{AWW}$ incubated at $37^{\circ} \mathrm{C}$ for two days in a rotary shaker at $100 \mathrm{rpm}$.

Mainly this observation was due to the correlations in the results of the percentage of adsorption, the concentrations in the beads and the SEM-EDX detections. As shown previously in Error! Reference source not found., the highest percentage of adsorption between $\mathrm{Cd}$ and $\mathrm{Ag}$ was of $\mathrm{Ag}$ adsorption, and later XRF analysis showed a higher concentration of $\mathrm{Ag}$ within the beads than the concentration of Cd. Also, SEM-EDX studies showed peaks of other elements in the control beads (Figure 3A and 4A), Cd-loaded Na-alginate beads (Error! Reference source not found.B) and Ag- 
loaded Na-alginate beads (Error! Reference source not found.B) such as carbon (C), $\mathrm{Na}$ and $\mathrm{Ca}$ mainly from bead's composition, phosphate $(\mathrm{P})$, chloride $(\mathrm{Cl})$ and oxygen $(\mathrm{O})$ from the composition of AWW; while the peaks of osmium (Os) were from Os that used in the fixation method and the peaks of $\mathrm{Au}$ was from the handling of gold in the coating samples. The ICP-MS analysis of beads showed that the total concentrations of $\mathrm{Cd}$ and $\mathrm{Ag}$ were $51 \pm 2.6 \mu \mathrm{g} \mathrm{Cd} / \mathrm{g}$ dry and $74.2 \pm 3.5 \mu \mathrm{g} \mathrm{Ag} / \mathrm{g}$ dry, which they were equal to the concentrations that obtained by XRF (Table 1).

\section{Conclusions:}

Overall, although undirected, approximate estimated and complicated method (peak detectionbased (SEM-EDX) has been used in the inaccurate estimation of elements generally and of $\mathrm{Cd}(23)$ and $\mathrm{Ag}$ (24) especially. The present study reported the first use of XRF in the direct analysis of an example of elements, $\mathrm{Cd}$ and $\mathrm{Ag}$, which were absorbed within the Na-alginate beads in batch adsorption experiments. The advantages of using of XRF for direct analysis of $\mathrm{Cd}$ and $\mathrm{Ag}$ within the beads shown the concentrations of either $\mathrm{Cd}$ and $\mathrm{Ag}$ were in $\mu \mathrm{g} / \mathrm{g}$ dry weight is not like the detections of $\mathrm{Cd}$ and $\mathrm{Ag}$ by SEM-EDX, which show the peaks of either $\mathrm{Cd}$ and $\mathrm{Ag}$ in cps/EV (Counts per second per electron-volt, $\mathrm{keV}$ : kilo electron-volt). This $\mu \mathrm{g} / \mathrm{g}$ is the precise unit for measuring and concentrations of $\mathrm{Cd}$ and $\mathrm{Ag}$ or other elements rather counting the electron per second of each element by SEM-EDX. In addition to the lack of fixation method or SEMEDX observation, where including toxic chemicals and time-consuming. Finally, digestion of the bead before analyzing by ICP-MS is sometimes not sufficient to liberate the elements from the beads. These finding of the recorded concentrations of $\mathrm{Cd}$ and $\mathrm{Ag}$ within Na-alginate beads by direct analysis of XRF providing the overall possible analysis of other elements and monitoring across an application procedure in a biotechnology sector to be directly related with other analytical chemistry methods.

\section{Author's declaration:}

- Conflicts of Interest: None.

- I hereby confirm that all the Figures and Tables in the manuscript are mine. Besides, the Figures and images, which are not mine, have been given permission for re-publication attached to the manuscript.

- Ethical Clearance: The project was approved by the local ethical committee in the University of Babylon.

\section{References:}

1. Jebril N.M.T. In Vitro Bioremediation: A Development Process of Cadmium and Mercury Removal by Environmental Biotechnologies of UVMutated Escherichia coli $\mathrm{K} 12$ and Bacillus subtilis 168. BSJ..2020a;17(1(Suppl.):244-254.

http://bsj.uobaghdad.edu.iq/index.php/BSJ/article/vie w/5011

2. Celik KH, Bayraktar E, Mehmetoglu Ü. Production of precursors for anti-Alzheimer drugs: Asymmetric bioreduction in a packed-bed bioreactor using immobilized D. carota cells, Prep Biochem Biotechnol. 2017; 47: 67-73. https://doi.org/10.1080/10826068.2016.1168840.

3. Damayanti A, Sediawan WB, Syamsiah S. Performance analysis of immobilized and coimmobilized enriched-mixed culture for hydrogen production, JMES. 2018; 12:3515-3528.

https://doi.org/10.15282/jmes.12.1.2018.18.0312.

4. Ahmad A, Bhat A, Buang A. Biosorption of transition metals by freely suspended and Ca-alginate immobilised with Chlorella vulgaris: Kinetic and equilibrium modeling, J Clean Prod. 2018; 171:13611375. https://doi.org/10.1016/j.jclepro.2017.09.252.

5. Rahim SNA, Sulaiman A, Hamzah F, Hamid KHK, Rodhi MNM, Musa M, et al. Enzymes encapsulation within calcium alginate-clay beads: characterization and application for cassava slurry saccharification, Procedia Eng. 2013; 68: 411-417. https://doi.org/10.1016/j.proeng.2013.12.200.

6. Sankarraj N, Nallathambi G. Immobilization and haracterization of cellulase on concanavalin A (Con A)-layered calcium alginate beads, Biocatal. Biotransformation. 2015; 33: 81-88. https://doi.org/10.3109/10242422.2015.1040004.

7. Vinci A, Zoli L, Galizia P, Kütemeyer M, Koch D, Sciti D. Reactive melt infiltration of carbon fibre reinforced $\mathrm{ZrB} 2 / \mathrm{B}$ composites with $\mathrm{Zr} 2 \mathrm{Cu}$. Compos. Part A Appl. Sci. Manuf. 2020; 137 (105973): 1-8. https://doi.org/10.1016/j.compositesa.2020.105973

8. Bensouici A, Carcelen V, Plaza J, De Dios S, Vijayan $\mathrm{N}$, Crocco J, et al. Study of effects of polishing and etching processes on Cd1- xZnxTe surface quality. $J$ Cryst Growth. 2010; 312(14): 2098-2102. https://doi.org/10.1016/j.jcrysgro.2010.03.045

9. Zhou Y, Zhang F, Tang L, Zhang J, Zeng G, Luo L, et al. Simultaneous removal of atrazine and copper using polyacrylic acid-functionalized magnetic ordered mesoporous carbon from water: adsorption mechanism. Sci. Rep. 2017;7:43831.

10. West M , Ellis A.T, Potts P.J, Streli C., Vanhoof C and Wobrauschek P. Atomic Spectrometry Update-a review of advances in X-ray fluorescence spectrometry. J Anal At Spectrom. 2014; 29:15161563. https://doi.org/10.1039/C4JA90038

11. Vanhoof C, Bacon J.R, Ellis A.T, Fittschen U.E, and Vincze L. atomic spectrometry update-a review of advances in X-ray fluorescence spectrometry and its special applications. J Anal At Spectrom. 2019; 34, 1750-1767. https://doi.org/10.1039/C9JA90042J.

12. Carter S, Clough R, Fisher A, Gibson B, Russell B, Waack J. Atomic spectrometry update: review of advances in the analysis of metals, chemicals and 
materials. J Anal At Spectrom. 2019; 34 (11):2159216. https://doi.org/10.1039/C9JA90058F.

13. Bacon JR, Butler OT, Cairns WRL, Cook JM, Davidson CM, Cavoura O, et al. Atomic spectrometry update - a review of advances in environmental analysis. J Anal At Spectrom. 2020; 35(1):9-53. https://doi.org/10.1039/C9JA90060H.

14. Evans EH, Pisonero J, Smith CMM, Taylor RN. Atomic spectrometry update: review of advances in atomic spectrometry and related techniques. J Anal At Spectrom. 2020; 35(5):830-51. https://doi.org/10.1039/D0JA90015J.

15. Bull A, Brown MT, Turner A. Novel use of fieldportable-xrf for the direct analysis of trace elements in marine macro algae, Environ Pollut. 2017; 220:228-233.

https://doi.org/10.1016/j.envpol.2016.09.049

16. Mujtaba G, Rizwan M, Kim G, Lee K. Removal of nutrients and COD through co-culturing activated sludge and immobilized Chlorella vulgaris, Chem Eng J. 2018; 343: 155-162.

https://doi.org/10.1016/j.cej.2018.03.007.

17. Kondaveeti S, Cornejo DR, Petri DFS. Alginate/magnetite hybrid beads for magnetically stimulated release of dopamine, Colloids Surf. B. (2016); 138: 94-101. https://doi.org/10.1016/j.colsurfb.2015.11.058.

18. de Carvalho GGA, Kondaveeti S, Petri DF, Fioroto AM, Albuquerque LG, Oliveira PV. Evaluation of calcium alginate beads for $\mathrm{Ce}, \mathrm{La}$ and $\mathrm{Nd}$ preconcentration from groundwater prior to ICP OES analysis, Talanta. 2016; 161: 707-712. https://doi.org/10.1016/j.talanta.2016.09.027.

19. Turner A, Solman KR. Analysis of the elemental composition of marine litter by field-portable-XRF, Talanta. 2016; 159: 262-271.

https://doi.org/10.1016/j.talanta.2016.06.026.

20. Jebril N.M.T. Evaluation of two fixation techniques for direct observation of biofilm formation of Bacillus subtilis in situ, on Congo red agar, using scanning electron microscopy, Vet. World, 2020b; 13(6): 11331137.http://www.veterinaryworld.org/Vol.13/June2020/16.html

21. Jebril, N.M.T. Systems biology design of the microbe toward the bioremediation of cadmium: a review. 2020c; 24(8): 9160-9166,

https://www.psychosocial.com/article/PR280906/254 $\underline{291}$

22. Nasrullah A, Bhat A, Naeem A, Isa MH, Danish M. High surface area mesoporous activated carbonalginate beads for efficient removal of methylene blue, Int J BiolMacromol. 2018; 107: 1792-1799. https://doi.org/10.1016/j.ijbiomac.2017.10.045.

23. Rajesh V, Kumar ASK, Rajesh N. Biosorption of cadmium using a novel bacterium isolated from an electronic industry effluent, Chem Eng J. 2014; 235: 176-185.

https://doi.org/10.1016/j.cej.2013.09.016.

24. Pięta E, Lekki J, del Hoyo-Meléndez JM, Paluszkiewicz C, Nowakowski M, Matosz M, et al. Surface characterization of medieval silver coins minted by the early Piasts: FT-IR mapping and SEM/EDX studies, Surf Interface Anal. 2018; 50: 7886. https://doi.org/10.1002/sia.6338.

\title{
استخدام جديد د XRF في عمليات الامتزاز للتحليل المباشر للكادميوم والفضة في حبيبات Na- ألجينات \\ نادية محمود توفيق جبريل
}

\begin{abstract}
قسم علوم الحياة، كلية العلوم للبنات، جامعة بابل، العر اق
حبة النجيليات الممتزة بالعناصر كالصوديوم شائعة الاستخدام في مجالات التكنولوجيا الحيوية بسبب التبادل الأيوني بين

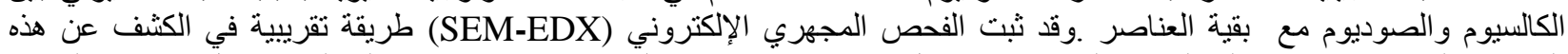

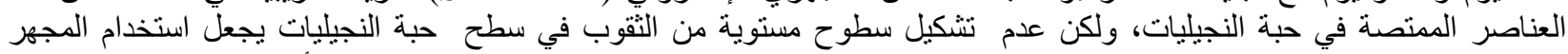

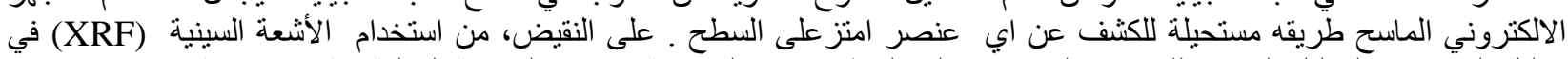

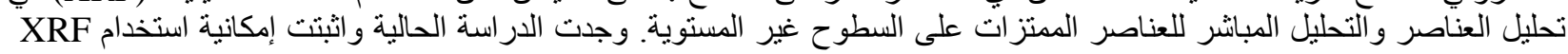

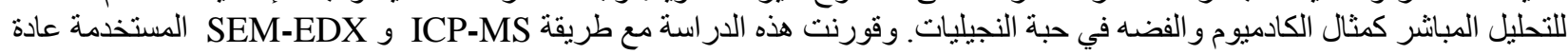

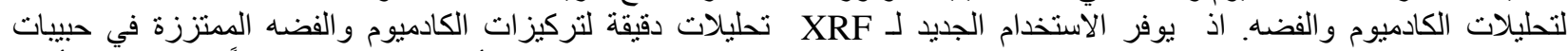

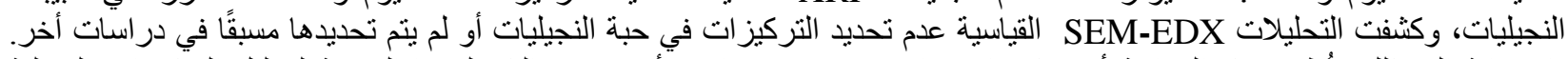

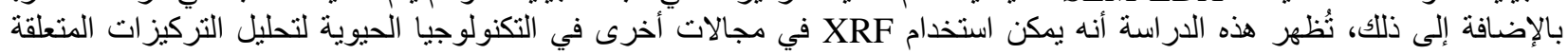

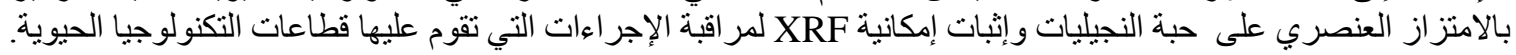

